\title{
Zpravodajové a senáty: Vliv složení senátu na rozhodování Ústavního soudu České republiky o ústavních stížnostech*
}

\author{
Judge Rapporteur and the Panel: On the Influence of the \\ Panel Composition on Decisions of the Constitutional Court \\ of the Czech Republic about Constitutional Complaints
}

\author{
Jan Chmel $^{* *}$
}

\begin{abstract}
Abstrakt
Článek se vènuje otázce, jaký vliv má složeni senátu Ústavního soudu na rozhodnutí o ústavni stǐ̌nosti, konkrétné nakolik výsledek rozhodnutí závisi na miře ustrícnosti soudce zpravodaje a nakolik na mire vstrícnosti ostatnich členu senátu. Tuto otázku nejprve zasazuje do kontextu obecné teorie senátního rozhodováni a následnè empiricky zkoumá v roz̧odnutich Ústavního soudu. Na teoretické úrovni jsou formulovány trì základni uicely senátníbo rozhodování: posileni legitimity rozhodnutí, eliminace chyb a dosaženi promyšlenèjšibo roz̧hodnutí, a čtyri modely senátního rozhodováni: konfliktní senát, strategické senát, kolegiálni senát a formálni senát. Objasnèn je pojem a možnéprǐciny tzv. panelového efektu v senátním roz̧odování. V rámci vlastního výzkumu je pak analyzováno, nakolik jsou uvedené funkce naplñovány v rozhodování Ústavního soudu, kterému z. modelu se senáty Ústavníbo soudu nejvice bliží a żda se v senátním rozhodování projevije panelový efekt. Výzkum dospivá k závèru, že výsledek rǐzeni o ústavnich stižnostech závisi primárnè na osobè soudce zpravodaje a jen minimálnè na osobách dalšich členu senátu. Senáty Ústavníbo soudu se proto nejvice blǐ̌i formálnimu modelu fungováni senátu a panelový efekt se v nich projevuje jen minimálnè.
\end{abstract}

Klíčová slova

Ústavni soud Ceské republiky;; senátní roz̧bodováni; vliv soudce zpravodaje; vliv členu senátu; panelový efekt.

\section{Abstract}

The article deals with the influence of the composition of the panel of the Constitutional Court of the Czech Republic on the decision about a constitutional complaint. In particular a question is posed, to what extent does the result depend on the judge rapporteur and to what extent on other members of the panel? At first, the author analyses the theoretical context of the question and after that conducts an empirical research. On the theoretical level, three basic functions of panel decision-making are recognized: legitimacy-strengthening, mistake-correction and achieving deeper consideration of the decision. After that, four types of judicial panel are distinguished: adversarial, strategic, collegial and formal panel. The theoretical part also clarifies the concept and causes of the so-called panel effect. The empirical research analyses, which type of panels

* Článek vznikl v rámci řešení grantu podpořeného Grantovou agenturou ČR č. 17-08176S: Ústavní soud ČR: strážce ústavy nad politikou nebo $\mathrm{v}$ politice. Za podnětné poznámky a připomínky $\mathrm{k}$ textu děkuji Kristině Blažkové, Janu Kyselovi, Janě Ondřejkové a Janu Wintrovi.

** Mgr. Jan Chmel, doktorand, Katedra teorie práva a právních učení, Právnická fakulta, Univerzita Karlova, Praha / Ph.D. student, Department of Legal Theory and Legal Doctrines, Faculty of Law, Charles University, Prague, Czech Republic / E-mail: janchmel@gmail.com / ORCID: 0000-0003-2628-1042 
occurs at the Constitutional Court, how does the panel decision-making of the Constitutional Court fulfil its functions, and whether the panel effect can be observed. The author concludes, that the result of the proceedings about a constitutional complaint depends primarily on the judge rapporteur and the influence of other panel members is weak. The Constitutional court panels thus resemble the model of formal panel. The panel effect is insignificant in the panel decision-making of the Constitutional court.

\section{Keywords}

Constitutional Court of the Czech Republic; Panel Decision-making; Influence of Judge Rapporteur; Influence of Panel Members; Panel Effect.

\section{1 Úvod: vstř́ícní soudci, nebo vstřícné senáty?}

„Mít jako zpravodajku Elišku Wagnerovou se rovnalo malé výhře v loterii,“ konstatoval novinář Tomáš Němeček v životopisné knize z roku 2014 věnované právě této významné osobnosti českého ústavního soudnictví, ${ }^{1}$ když kritizoval vysoké rozpětí v míře vstř́icnosti, jakou vykazují jednotliví soudci Ústavního soudu České republiky (dále též „Ústavní soud“). Podle jeho zjištění se rozpětí procenta případů, v nichž soudci z pozice soudce zpravodaje vyhověli ústavní stížnosti, pohybovalo od pouhých 2,6 \% u Vladimíra Kůrky po 13,5 \% u Elišky Wagnerové. Nejedná se přitom o ojedinělou kritiku, na značně nejednotný prrístup jednotlivých soudců k ústavním stížnostem upozornila i právní věda, např́iklad Tereza Papoušková a Jan Papoušek ${ }^{3}$ či Zdeněk Kühn, ${ }^{4}$ který navíc shodně s Ondřejem Kadlecem ${ }^{5}$ upozorňuje, že odlišnost př́stupů jednotlivých soudců je ještě dramatičtější, pokud odhlédneme od kauz, k nimž již existuje předchozí judikatura Ústavního soudu, a budeme si všímat jen nových otázek. Rozdílné míre vstřícnosti jednotlivých soudců zpravodajů Ústavního soudu byla věnována i určitá mediální pozornost, ${ }^{6}$ což svědčí o tom, že tento jev je i veřejností vnímán jako problematický. Důvody

1 Viz NĚMEČEK, T. Padni komu padni. Život a př̌pady Elišky Wagnerové. Praha: Leges, 2014, s. 105.

2 Již úvodem považuji za vhodné poznamenat (byt’ z textu je to zřejmé), že „vstř́cnost“ v celém textu používám výhradně jako pracovní pojem, který vyjadřuje míru, v jaké daný soudce vyhovuje ústavním stížnostem.

3 Viz PAPOUŠKOVÁ, T. a J. PAPOUŠEK. Ústavní soudci v kvantitativní perspektivě. Časopis pro právní vědu a praxi, 2017, r. 25, č. 1, s. 79. DOI: 10.5817/CPVP2017-1-5. Dostupné z: https://journals.muni.cz/ cpvp/article/view/6657

4 Viz KÜHN, Z. Ústavní soud České republiky: Proměny instituce v průběhu dvou desetiletí. In: GERLOCH, A. a J. KYSELA. 20 let Ústavy Ceské republiky. Oblédnuti zpět a pobled vpréd. Plzeň: Aleš Čeněk, 2013, s. 255 .

5 Viz KADLEC, O. Metodologie interpretace práva v judikature Ústavního soudu ČR. Praha, 2013. Diplomová práce. Univerzita Karlova, Právnická fakulta.

6 Viz ČTK. Mezi ústavními soudci byly rozdíly v rychlosti $i$ vstř́cnosti. [online]. 28. 4.2017 [cit. 15. 9. 2017]. Dostupné z: http://www.ceskenoviny.cz/zpravy/mezi-ustavnimi-soudci-byly-rozdily-v-rychlosti-i-vstricnosti/1478796; či ČESKÁ TELEVIZE. Nejustrícnèjš́ Šimáčková, nejmenši naděje u Suchánka. Rozdíly v rozhodování ústavních soudcu jsou velké. [online]. 28. 4. 2017 [cit. 15. 9. 2017]. Dostupné z: http://www. ceskatelevize.cz/ct24/regiony/2102429-nejvstricnejsi-simackova-nejmensi-nadeje-u-suchanka-rozdily-v-rozhodovani-ustavnich 
jsou zjevné: od Ústavního soudu intuitivně očekáváme, že spíše než podle „nastaveni““ jednotlivých soudců bude rozhodovat podle (ústavního) práva, které je pro všechny soudce stejné. Jeví se jako nespravedlivé, aby osud ústavní stížnosti ve značné míře závisel na nahodilé skutečnosti: kterému zpravodajovi stížnost přijde na stůl.

V rámci uvedené kritiky bývá různá míra vstřícnosti automaticky připisována jednotlivým soudcům zpravodajům - ostatně podle statistik lze skutečně rozdíly u jednotlivých zpravodajů pozorovat. Pozornost již nebývá věnována tomu, že soudci ve skutečnosti ve většině př́padů o ústavních stížnostech rozhodují ve tříčlenném senátu a nález či usnesení je tak obvykle přinejmenším formálně výsledkem kolektivního rozhodnutí. Podle ustanovení \43 zákona č. 182/1993 Sb., o Ústavním soudu („,zákon o Ústavním soudu“) může sám soudce zpravodaj odmítnout ústavní stížnost z čistě procesních důvodů jako je např. opožděnost, zjevná neoprávněnost navrhovatele nebo nepřípustnost návrhu. Rozhodnutí celého senátu je nutné pro meritorní nález, kterým se ústavní stížnost zamítá nebo se jí vyhovuje, ale i pro kvazimeritorní usnesení o odmítnutí stížnosti pro zjevnou neopodstatněnost. ${ }^{7}$

Role soudce zpravodaje v rozhodovacím procesu je důležitá, neměla by však být výlučná: jeho úkolem je vedle provádění procesních úkonů především prríprava věci k projednání v senátu, ${ }^{8}$ což v praxi obnáší zejména prípravu zpravodajské zprávy obsahující návrh rozhodnutí. ${ }^{9}$ Lze přirozeně očekávat, že výsledné rozhodnutí nezáleží jen na názoru soudce zpravodaje - ten může být svými kolegy přehlasován, přesvědčen v rámci debaty, nebo jej může již při sepisování zpravodajské zprávy ovlivnit už sama skutečnost, že zná své kolegy a tuší, jaké rozhodnutí budou preferovat.

Výsledky tuzemské právní vědy však prozatím nedávají jasnou odpověd’ na otázku, zda je uvedené očekávání vlivu dalších členů senátu na rozhodnutí naplňováno. V posledních několika letech došlo k rychlému rozvoji empirického výzkumu rozhodování Ústavního soudu a faktorů, které jej ovlivňuji. ${ }^{10}$ Pozornost je věnována např́íklad vlivu, který

7 Z celkového počtu 67711 rozhodnutí vydaných Ústavním soudem od jeho vzniku do 31. 8. 2017 evidovaných v databázi NALUS ke dni 11. 11. 2017 bylo v asi 7 \% př́padů rozhodnuto nálezem o vyhovění nebo zamítnutí stížnosti a v dalších přibližně 59 \% případů byla stížnost odmítnuta pro zjevnou neopodstatněnost. Zbylá rozhodnutí jsou z většiny tvořena usneseními odmítajícími stížnost procesních důvodů. 1035 evidovaných rozhodnutí má pak čistě procesní charakter a nekončí se jimi řízení. Zjištěno z dat dostupných v databázi rozhodnutí Ústavního soudu NALUS na http://nalus.usoud.cz

8 Ust. \42 zákona o Ústavním soudu.

9 Viz podrobněji HOŘEŇOVSKÝ, J. a J. CHMEL. Proces vzniku rozhodnutí Ústavního soudu ČR. Časopis proprámí védu a praxi, 2015, r. 23, č. 3, s. 302-311. Dostupné z: https://journals.muni.cz/cpvp/ article/view/5299

10 Zásluhy za cenné př́inosy v této oblasti je na místě přičítat zejména Právnické fakultě brněnské Masarykovy univerzity, kde se vedle řady článků a diplomových prací tématu věnuje např́iklad Judicial Studies Institute pod vedením Davida Kosaře, vyučovaný předmět Mimoprávní vlivy na rozhodováni soudü, či shodně nazvaný několikaletý projekt podpořený Grantovou agenturou ČR. Tématu byly věnovány též sekce některých konferencí v letech 2016 a 2017. Tématu se vedle toho věnuje i katedra politologie a sociologie Právnické fakulty pražské Univerzity Karlovy. 
na rozhodování má osobnost soudcư ${ }^{11}$, jejich profesní minulost, politické přesvědčení, morálně-filosofické názory. ${ }^{12}$ Ukazuje se, že i na takovýchto faktorech záleží a rozhodně tak není lhostejné, který soudce tu kterou věc rozhoduje. Prozatím však bývají - s čestnými výjimkami ${ }^{13}$ - spíše přehlíženy ty $z$ faktorů ovlivňujících rozhodnutí, které jsou z hlediska soudce zpravodaje externí, jako je například veřejné mínění, názory relevantních politických aktérů, ale právě i vliv dalších členů senátu či pléna na zpravodaje.

Ke zkoumání posledního uvedeného faktoru se empirickou formou pokusí drobným dílkem přispět tento článek. Jeho cílem bude zjistit, nakolik má na rozhodování Ústavního soudu o ústavních stížnostech, resp. na procentuální míru vyhovění stížnostem, vliv osoba soudce zpravodaje a nakolik osoby dalších členů senátu. Tato otázka je aktuální nejen s ohledem na probíhající rozvoj výše zmíněného výzkumu faktorů ovlivňujících soudní rozhodování, ale také s ohledem na relativně novou změnu pravidel pro obsazování senátů Ústavního soudu, jejichž složení se počínaje rokem 2016 každé dva roky pravidelně obměňuje. ${ }^{14}$ Zkoumané otázky se pokusím zasadit do obecnějšího teoretického kontextu úvah o smyslu a fungování senátního rozhodování soudů. Samotný empirický výzkum bude proveden kvantitativní statistickou metodou a jeho výsledky tak budou ukazovat pouze obecné trendy, nikoliv analyzovat jednotlivé př́pady. To je vhodné brát při hodnocení výsledků na vědomí.

\section{Teorie senátního rozhodování}

\subsection{Funkce soudních senátů a jejich vnímání soudci}

Lze identifikovat tři základní vzájemně propojené funkce senátního rozhodování soudů - důvody, proč je vhodné, aby na vysokých soudech rozhodovaly vícečlenné senáty, a ne pouze jednotliví soudci. Těmi jsou 1) posílení legitimity, 2) eliminace chyb a 3) dosažení promyšlenějšího řešení př́padu. (1) Potřeba vyšší legitimity je u vysokých soudů dána skutečností, že zpravidla přezkoumávají postup hned několika soudních instancí tedy i několika soudců, kteř́ již vyslovili svůj názor na daný př́ípad. V případě rozhodnutí Ústavního soudu o ústavních stížnostech je navíc rozhodnutí konečné a neexistuje proti němu vnitrostátní opravný prostředek. Bylo by tak v principu problematické a snižovalo by faktický respekt k rozhodnutím Ústavního soudu, pokud by šlo o rozhodnutí jediné

11 Viz KYSELA, J., K. BLAŽKOVÁ, J. CHMEL a kol. Právnický Olymp. Portréty vybraných soudcu Ústavního soudu ČR. Praha: Leges, 2015; či ŠULA, P. Osobnost soudce a mezisondcovské vztaby jako faktor ovlivñujici roz̧hodováni Ústavního soudu. Brno, 2017. Diplomová práce. Masarykova univerzita. Právnická fakulta.

12 Viz BERNARD, V. Morální filosofie v judikatuře Ústavního soudu. Brno, 2017. Diplomová práce. Masarykova univerzita. Právnická fakulta.

13 Viz KOZUBÍK, J. a J. WINTR. Ústavní soudy a práva gayů a leseb - veřejné mínění jako determinant rozhodnutí soudů. Jurisprudence, 2016, č. 5. s. 34-47; či ŠULA, P., op. cit., sub 11.

14 Viz rozhodnutí pléna Ústavního soudu ze dne 8. 12. 2015 č. j. Org. 60/15. 
osoby. Po věcné stránce pak kolektivní rozhodování (2) snižuje pravděpodobnost, že dojde ke zjevné chybě jako například přehlédnutí relevantní právní úpravy či judikatury jednoduše řečeno, „víc očí víc vidî“. ${ }^{15}$ I poslední ze zmíněných důvodů, kterým je (3) nalezení promyšlenějšího řešení případu, lze vyjádřit tradičním úslovím: „víc hlav víc ví“. Může být předmětem sporu, zda kolektivní rozhodování vede, či nevede k řešením, která jsou v určitém smyslu věcně správnějšši ${ }^{16}$ a zda taková řešení v oblasti ústavního práva vưbec existují. V každém př́padě má však kolektivní rozhodování potenciál umožnit zevrubnou debatu o řešeném problému, v níž dojde $\mathrm{k}$ důkladnému zvážení širokého spektra argumentů. To platí tím spíše, že jednotlivé osobnosti soudců mohou mít značně odlišné profesní, hodnotové i intelektuální zázemí a mohou tak do debat přinášet rưzné perspektivy.

Zmíněné funkce senátního rozhodování se však realizují $\mathrm{v}$ různé míře $\mathrm{v}$ závislosti na skutečné podobě fungování senátů toho kterého soudu. V každém př́ípadě platí, že senátní rozhodování není, nebo by nemělo být, stejné jako rozhodování samosoudce. Důvody jsou zřejmé na první pohled: většina senátu může přehlasovat menšinu, názory soudců a jejich hlasování mohou být ovlivněny senátními poradami, strategickými úvahami o tom, jaký názor u kolegů „projde“, nebo rizikem, že některý z kolegů poukáže na nedostatky argumentace v odlišném stanovisku. Přijatá rozhodnutí tak mohou být výsledkem kompromisu. Na druhé straně, soudci si naopak mohou navzájem důvěřrovat a spoléhat se na názory senátních kolegů, popřípadě neprojevovat nesouhlas s názorem soudce zpravodaje v očekávání podobně shovívavého př́stupu kolegů ke svým vlastním návrhům $\mathrm{v}$ budoucnu.

Rozhodování soudních kolektivních těles obecně může přinášet řadu těsných hlasování i názorových střetů. Tomu odpovídá např́iklad výrok amerického soudce Olivera W. Holmese, který údajně kdysi slavně přirovnal Nejvyšší soud USA k „devíti škorpionuim $v$ labvi “' ${ }^{17}$ Výrok se však vztahoval k soudu, který rozhoduje v devítičlenném plénu a navíc disponuje mechanismy selekce nápadu takže se věcně věnuje menšímu počtu př́padů. Lze si sice představit podobnou atmosféru i v rámci menších senátů, je však pravděpodobnější, že menší rozhodovací tělesa vytvářejí odlišné mezilidské vztahy a situace: soudci znají své kolegy, mohou již předem přizpůsobovat své návrhy jejich názorům nebo předcházet konfliktům neprojevením př́padného nesouhlasu. Tomu odpovídají třeba i zkušenosti ze senátního rozhodování, které ve svých článcích popsali soudci amerických federálních odvolacích soudců Diane P. Wood, Frank M. Coffin a Harry

$15 \mathrm{~K}$ této funkci senátního rozhodování srov. též. CAMINKER, E. H. Sincere and Strategic Voting Norms on Multimember Courts. Michigan Law Review, 1999, r. 97, s. 2297-2380.

16 Pro kladnou odpověd’ argumentují např. KORNHAUSER, L. A. a L. G. SAGER. Unpacking the Court. Yale Law Journal, 1986, r. 96, s. 82-118.

17 Viz CROSS, F. B. a E. H. TILLER. Understanding Collegiality on the Court. University of Pennsylvania Journal of Constitutional Law, 2008, r. 10, č. 2, s. 259. 
T. Edwards. Podle Diane Wood je např́klad v senátním rozhodování někdy „nejlepší podvolit se cizímu názoru a schovat si nesouhlas na jindy. “18 Frank Coffin zase popisuje a vyzdvihuje zkušenost kolegiálního soudu (viz k tomu níže), na němž soudci v senátech spíše, než aby za každou cenu prosazovali svi̊j vlastní pohled nebo bez dalšího hlasovali podle svého, spolupracují, aby dosáhli co nejlepších rozhodnutí, a to za vzájemného respektu a snahy dosáhnout porozumění a kompromisu. ${ }^{19}$ Podobně Harry Edwards klade důraz na to, že federální odvolací soud pro District of Columbia Circuit, jehož byl řadu let předsedou, funguje kolegiálně a jeho soudci otevřeně diskutují a berou názory ostatních soudců vážně a s otevřenou myslí. ${ }^{20}$

Senátní rozhodnutí ovšem nemusí být nutně výsledkem konfliktu ani složité diskuze. Mezi soudci totiž může panovat důvěra vedoucí k následování názoru jiného soudce. Podle dostupných informací se právě taková důvěra projevuje i v rozhodování Ústavního soudu o ústavních stížnostech, což kontrastuje s plenárním rozhodováním. ${ }^{21}$ Anekdoticky, byt' pouze ve vztahu k jedné právní oblasti, to např́iklad vyjádřila Iva Brožová v knize již zmíněného Tomáše Němečka o Vojtěchu Ceplovi, jejím kolegovi z druhého senátu „prvního“ Ústavního soudu. ${ }^{22}$ Podle ní, šlo-li občanské právo procesní, razil soudce Cepl heslo: „Kudy Božka, tudy já‘. ${ }^{23}$ Předseda Ústavního soudu Pavel Rychetský zase ve svých vzpomínkách popisoval, že on sám návrh rozhodnutí, který připraví se svými asistenty, posílá senátním kolegům ${ }^{24}$ elektronickou cestou, přičemž v $90 \%$ pŕípadů se senát ani nemusí fyzicky scházet - schází se tedy jen, pokud se objeví nějaký problém, pokud to některý soudce požaduje. ${ }^{25}$ Lze se domnívat, že při takové podobě rozhodování je přeci jen role vzájemného názorového konfliktu i právní debaty limitovanější. Otázka, nakolik na Ústavním soudu senátní rozhodování plní své funkce, bude podrobněji zkoumána $\mathrm{v}$ druhé polovině této práce.

Podoba spolupráce soudců může záviset mimo jiné na institucionálních faktorech, jako je již zmiňovaná nedávno zavedená pravidelná „rotace“ senátů na Ústavním soudě. V roce 2015 v době, kdy bylo zavedení rotace zvažováno, popisoval Pavel Rychetský,

18 WOOD, D. P. When to Hold, When to Fold, and When to Reshuffle: The Art of Decisionmaking on a Multi-Member Court. California Law Review, 2012, r. 100, č. 6, s. 1447.

19 Viz COFFIN, F. M. On Appeal: Courts, Lanyering and Judging. New York and London: W. W. Norton \& Co., 1994, s. 215.

20 Viz EDWARDS, H. T. Collegiality and Decision Making on the D.C. Circuit, Virginia Law Review, 1998, r. 84 , s. $1335-1370$.

21 Viz též HOŘEŇOVSKÝ, CHMEL, op. cit., sub 9.

22 Přehledné znázornění vývoje složení senátů Ústavního soudu od jeho vzniku až do současnosti podávajî T. Papoušková a J. Papoušek. Viz PAPOUŠKOVÁ, PAPOUŠEK, op. cit., sub 3.

23 Viz NĚMEČEK, T. Vojtěch Cepl. Život právnika ve 20. století. Praha: Leges, 2010, s. 130.

$24 \mathrm{~V}$ př́padě Pavla Rychetského jako soudce zpravodaje přitom nebylo složení senátu stabilní s ohledem na jeho funkcionářskou pozici.

25 Viz NĚMEČEK, T. Pavel Rychetský. Diskerétni zóna. Praha: Vyšehrad, 2012, s. 211. 
že ustálené složení senátů prináší tu výhodu, že soudci si „,na sebe zvyknou a vytvoř určité efektivni metody práce. “ $\mathrm{Na}$ druhé straně problémem pak je, že „nenastává dostatečné názorové prolináni napríc Ústavním soudem. "26 V roce 2008 při argumentaci pro zavedení rotace senátů formuloval tehdejší soudce Nejvyššího správního soudu (a v současnosti soudce Ústavního soudu) Vojtěch Šimíček nadneseně mj. dva modely soudního senátu: ${ }^{27}$ „model spokojené rodinky "v níž se jednou ustanovené senáty nikdy nemění a soudci v tř́členném senátu spolu dobře vycházeji1 ${ }^{28}$ a v kontrastu k němu stojící „model atomové elektrárny“, $\mathrm{v}$ němž se bude pravidelně měnit složení senátů a bude tak docházet $\mathrm{k}$,okysličování“ senátního života a ,zdravému jiskření mezi soudci“. ${ }^{29}$

\subsection{Modely soudního rozhodování}

Rozhodování soudců v kolektivních tělesech je dlouhodobě předmětem zkoumání právní vědy a politologie a za povšimnutí stojí několik teoretických př́istupů k soudnímu rozhodování. ${ }^{30}$ Různé prŕstupy totiž předvídají různé praktické podoby senátního rozhodování. Zejména v USA se v posledních desetiletích značné popularitě těší tzv. postojový model soudního rozhodování (attitudinal model), který předpokládá, že v kolektivním rozhodování soudci jednoduše hlasují pro řešení případu, které preferují na základě svého ideologického přesvědčení. ${ }^{31} \mathrm{Na}$ teoretické úrovni postojovému modelu soudního rozhodování odpovídá představa soudního senátu, v němž výsledek záleží zkrátka na tom, jak

26 Viz JANUŠ, J. Pavel Rychetský: Ústavní soud má být názorově pluralitní i doktrinálně jednotný. Ceskéápoz̧ice [online]. 21. 12. 2015 [cit. 16. 9. 2017]. Dostupné z: http://ceskapozice.lidovky.cz/ustavni-soud-ma-byt-nazorove-pluralitni-i-doktrinalne-jednotny-p8d-/tema.aspx?c=A151218_191120_pozice-tema_lube

27 Viz ŠIMÍČEK, V. Rotující senáty? In: Jiné právo [online]. 3. 1. 2008 [cit. 15. 9. 2017]. Dostupné z: http:// jinepravo.blogspot.cz/2008/01/rotujc-senty.html

28 Šimíček tento model komentuje značně sarkasticky: „Dobrá parta totiž znamená dobré pracovní výsledky a tedy i kvalitni judikaturu, prostou od vyostrených a kontroverznich názoru. Stejnè jako v každé správné rodinè se i v dobrém senátu špinavé prádlo pere uvnitr, takę̌e zásadně nežádoucí je vỉbec uvažovat o prípadných disentech a podobných náznacích verejnè ventilovaného nesoublasu s právnimi názory. "Ibid.

29 Ibid.

30 Pro základní shrnutí různých teoretických pohledů na kolektivní soudní rozhodování viz např. QUINN, K. M. The Academic Study of Decision Making on Multimember Courts. California Law Review, 2012, r. 100, s. 1493-1502; pro rozlišení teorií soudního rozhodování obecně viz DYEVRE, A. Unifying the Field of Comparative Judicial Politics: Towards a General Theory of Judicial Behaviour. European Political Science Review, 2010, r. 2, č. 2, s. 297-327; či ONDŘEJKOVÁ, J. Modely analýzy rozhodovací činnosti soudo̊ na príkladu kauzy tzv. slovenských důchodů. In: KYSELA, J., J. ONDŘEJKOVÁ a kol. Jak se piše o soudech a soudcich: soudni moc v mezioborové perspektivě. Praha: Leges, 2012, s. 55 an.

31 Základy pro postojový model položil již ve 40. letech 20. století Herman Pritchett, na nějž později navázala řada dalších autorů. Viz PRITCHETT, C. H. Divisions of Opinion Among Justices of the U. S. Supreme Court, 1939-1941. The American Political Science Review, 1941, r. 35, č. 5, s. 890 an.; SEGAL, J. A. a A. D. COVER. Ideological Values and the Votes of U.S. Supreme Court Justices. The American Political Science Review, 1989, r. 83, č. 2, s. 557-565; či MARTIN, A. D., K. M. QUINN, T. W. RUGER a P. T. KIM. Competing Approaches to Predicting Supreme Court Decision Making. Perspectives on Politics, 2004, r. 2, c. 4 , s. 761 an. 
je (již předem) nastaveno přesvědčení většiny členů senátu. To je pravděpodobně až př́liš zjednodušená představa, která nemůže soudní rozhodování plně vystihovat. Postojový model ovšem pro výzkumy senátního rozhodování často představuje určité východisko, které je dále modifikováno dalšími zjištěními: předpokládá se, že soudci by chtěli hlasovat podle svého ideologického přesvědčení, avšak působí na ně i další faktory. V př́ipadě českého prostředí a senátního rozhodování Ústavního soudu o ústavních stížnostech je otevřenou otázkou, zda by bylo vưbec možné identifikovat ve všech případech rozhodování ideologický aspekt. Teoretický model soudního senátu, kde soudci hlasují podle předem existujícího vlastního „nastavení “ je však představitelný i zde - jednotliví soudci by mohli v senátě například bez dalšího hlasovat na základě toho, nakolik vstrrícný př́istup k ústavním stížnostem zastávají.

Výzkum senátního rozhodování ukazuje, že jedním z hlavních faktorů, které (přinejmenším v USA) zpravidla modifikují hlasování soudců v senátu, je tzv. panelový efekt (panel effect): $:^{32}$ at' už z jakéhokoliv důvodu, hlasování soudců závisí mimo jiné na tom, kteří kolegové s nimi tvoří senát („,panel“). Soudci ve většině a v menšině v senátu svůj postoj navzájem přizpůsobuji. ${ }^{33}$ Jednoduše to zřejmě jako první ukázal Richard Revesz v roce 1997: prozkoumal hlasování senátů federálního odvolacího soudu pro District of Columbia Circuit v segmentu environmentálních otázek, v nichž obecně platí, že soudci jmenovaní republikánským prezidentem hlasují výrazně konzervativněji, než nominanti demokratického prezidenta. Zjistil ale významný vliv složení senátu na hlasování jednotlivého soudce: pokud demokrat tvoří senát s dvěma republikány, hlasuje konzervativněji, než demokrat tvořící senát s dvěma demokraty. ${ }^{34}$ To, že panelový efekt funguje, později prokázaly i další výzkumy, které také zdůraznily, že hlasování stejně ideologicky naladěných soudců ovlivní i přítomnost jediného opačně naladěného kolegy v senátu. ${ }^{35}$ Další provedené výzkumy pak prokázaly existenci panelového efektu i na jiném, než

32 Petr Šula, který panelový efekt rozebírá ve své diplomové práci, překládá anglický pojem „panel effect“ slovy „,kolegiální efekt““ - viz ŠULA, Petr, op.cit. sub 11. Preferuji však doslovný překlad „panelový efekt", nebot' tento jev lze vysvětlit i jinými faktory, než je kolegialita, zejména strategickým chováním soudců - viz k tomu KIM, P. T. Deliberation and Strategy on the United States Courts of Appeals: An Empirical Exploration of Panel Effects. University of Pensylvania Law Review, 2009, r. 157, s. 1319-1381.

33 Viz např. QUINN, op. cit., sub 30; či KIM, op. cit., sub 32.

34 Viz REVESZ, R. L. Environmental Regulation, Ideology, and the D. C. Circuit. Virginia Law Review, 1997 , r. 83 , č. 8 , s. $1717-772$.

35 Viz CROSS, F. B. a E. H. TILLER. Judicial Partisanship and Obedience to Legal Doctrine: Whistleblowing on the Federal Courts of Appeals. Yale Law Journal, 1998, r. 107, č. 7, s. 2155-2176; či SUSTEIN, Cass A. a Thomas J. MILES. Do Judges Make Regulatory Policy? An Empirical Investigation of Chevron. University of Chicago Law Review, 2006, r. 73, s. 1717 an.; Jonathan P. Kastellec k tomu dodává, že šance menšinového soudce přesvědčit své kolegy je navíc ovlivněna tím, jak je ideologicky naladěn nadřízený soud - viz KASTELLEC, J. P. Hierarchical and Collegial Politics on the U.S. Courts of Appeals. Journal of Politics, 2011, r. 73, č. 2, s. 345-361. 
ideologickém podkladě: hlasování soudce v senátu ovlivňuje také pohlavíi ${ }^{36}$ či rasa ${ }^{37}$ jeho kolegů v senátě.

Panelový efekt bývá vysvětlován různě, ${ }^{38}$ zejména však dvěma možnými příčinami: soudci bud' znají své kolegy, a strategicky uvažují tak, aby dlouhodobě byli schopni prosazovat maximum svých preferencí a hledají tak vzájemné kompromisy, nebo tvoří kolegiální senát, v jehož rámci se navzájem ovlivňují svými poradami. Strategický model navazuje na shora zmíněnou představu postojového modelu, podle kterého se každý soudce $\mathrm{v}$ zásadě snaží v rozhodování maximálně prosadit své vlastní preference. Přesto strategický model předpokládá, že i ideově heterogenní senát vytváří kompromisní rozhodnutí, která závisí na všech třech soudcích, nikoliv pouze na dvou, kteří mají většinu. ${ }^{39}$ Hledání kompromisu se může projevit zejména při formulaci odůvodnění rozhodnutí, ale i v samotném hlasování o výsledku: strategicky uvažující soudce může např́klad hlasovat pro řešení, které považuje za „second best“ a odmítnout své preferované řešení, jen aby se vyhnul výsledku, kdy většinu získá výsledek, který zásadně odmítá (např. může preferovat vyhovění ústavní stížnosti, ale hlasovat pro její zamítnutí a připojení interpretativního výroku, pokud tím přesvědčí své zdrženlivé kolegy, aby stížnost neodmítli). Stejně tak připadá byt' čistě teoreticky - v úvahu, že by strategičtí soudci navzájem vyměňovali svou vzájemnou podporu $v$ různých prípadech.

Vysvětlení spojované s kolegialitou představuje optimističtější pohled na senátní rozhodování soudních senátů: zdůrazňuje, že senátní rozhodování je skupinový proces, v jehož rámci se soudci snaží nalézt co nejlepší řešení případů - což vzájemné debaty umožňují díky zohlednění širšího spektra argumentů a perspektiv. ${ }^{40}$ Kolegialita bývá spojována jednak s rovnou participací všech členů tělesa, jednak se spoluprací těchto

36 Viz BOYD, C. L., L. EPPSTEIN a A. D. MARTIN. Untangling the Causal Effects of Sex on Judging. American Journal of Political Science, 2010, r. 54, č. 2, s. 389-411; či PERESIE, J. L. Female Judges Matter: Gender and Collegial Decisionmaking in the Federal Appelate Courts. Yale Law Journal, 2005, r. 114, s. 1759-1790. Uvedené výzkumy shodně ukazují, že v případech týkajících se diskriminace rozhodují ženy ale také senáty, v nichž je jedna žena a dva muži, častěji ve prospěch oběti diskriminace.

37 Viz KASTELLEC, J. P. Racial Diversity and Judicial Influence on Appellate Courts. American Journal of Political Science, 2012, r. 57, č. 1, s. 167-184. Jonathan Kastellec ukazuje, že nejen jednotliví afroameričtí soudci, ale i senáty, v nichž sedí dva bílí a jeden afroamerický soudce, vykazují větší vstř́ícnost vůči afirmativní akci ve srovnání se senáty složenými z čistě bílých soudců.

38 Viz MARTIN, QUINN, RUGER, KIM, op. cit., sub 32. Z používaných vysvětlení ponechávám stranou to, podle něhož soudci zvažují, že některý z kolegů poukáže na nedostatky argumentace $\mathrm{v}$ odlišném stanovisku, což může omezit volnost v hlasování - viz k tomu QUINN, op. cit., sub 30, kterou lze (byt' s určitými výhradami) podřadit pod níže uvedené „strategické“ vysvětlení panelového efektu.

39 Viz EPPSTEIN, L., B. FRIEDMAN a N. STAUDT. On the Capacity of the Roberts Court to Generate Consequentional Outcomes. North Carolina Law Review, 2008, r. 86, s. 1299-1332; či CROSS, TILLER, op cit., sub 19.

40 Viz EDWARDS, H. T. The Effects of Collegiality on Judicial Decision Making. University of Penyslvania Law Review, 2003, r. 151, s. 1639-1656; či KORNHAUSER, SAGER, op. cit., sub 16. 
členů ve společném zájmu a potlačení zájmů individuálních ${ }^{41}$ - kolegiální soudci tak nelpějí na svém pohledu a jsou ochotni pod váhou argumentů změnit původní názor. ${ }^{42}$ Kolegiální soud tedy v literatuře představuje určitý ideál. Výrazný proponent kolegiality na soudech, výše citovaný Harry Edwards, ostatně výslovně kritizuje postojový a strategický model soudního rozhodování s tím, že jsou př́liš individualistické a kolegialitu přehlížejí. ${ }^{43}$

Při analýze senátního rozhodování je ovšem nutné brát v potaz nejen postoje členů senátu a existenci panelového efektu, ale také skutečnost, že soudci nemají na rozhodování nekonečné množství času, a vedle snahy prosadit své řešení př́padu mohou mít i řadu jiných priorit. Jak přesvědčivě připomíná Richard A. Posner, soudce ovlivňují i takové cíle jako snaha získat dobrou reputaci či ušetřit volný čas. ${ }^{44}$ Soudci jsou racionální aktérí a senátní vyjednávání stejně jako psaní odlišných stanovisek je pro ně spojeno s různými druhy nákladů, a to zejména časových. ${ }^{45}$ To může být klíčový faktor zejména u soudů s vysokým nápadem, mezi které patří i Ústavní soud ČR. Klíčovou roli totiž může hrát soudce připravující návrh rozhodnutí, jemuž mohou ostatní soudci v rámci úspory času důvěřovat a schvalovat bez dalšího jím navržená řešení. V některých případech, které mohou tvořit větší či menší díl věcí rozhodovaných senátem, tak může být senátní rozhodování spíše jen formální.

41 Viz CROSS, TILLER, op cit., sub 19.

$42 \mathrm{~V}$ př́ipadě Nejvyššího soudu USA byla opakovaně empiricky testována hypotéza, že soudci mění svůj názor v mezidobí mezi předběžným a konečným hlasováním. Výsledky však ukázaly, že k tomu dochází jen výjimečně, v méně důležitých otázkách a zpravidla ve prospěch zjevné většiny soudců. Viz např. DORFF, R. H. a S. BRENNER. Conformity Voting on the United States Supreme Court. The Journal of Politics, 1992, r. 54, č. 3, s. 762-775; HAGLE, T. M. a H. J. SPAETH. Voting Fluidity and the Attitudinal Model of Supreme Court Decision Making. The Western Political Quarterly, 1991, r. 44, č. 1, s. 119-128; či BRENNER, S. a T. S. ARRINGTON. Ideological Voting on the Supreme Court: Comparing the Conference Vote and the Final Vote with the Segal-Cover Scores. Jurimetrics, 2001, r. 41, č. 4, s. 505 an.

43 Zajímavá je v tomto ohledu polemika mezi profesorem New York University School of Law Richardem Reveszem, který ve svých dílech poukazuje na vliv ideologických postojů soudců na jejich hlasování modifikovaný panelovým efektem, a Harry T. Edwardsem, soudcem federálního odvolacího soudu v District of Columbia a silným obhájcem kolegiality. Viz REVEZS, op. cit., sub 34; EDWARDS, H. T. Collegiality and Decision Making on the D. C. Circuit. Virginia Law Review, 1998, r. 84, s. 1335 an.; a REVESZ, R. L. Ideology, Collegiality and the D. C. Circuit: A Reply to Chief Judge Harry T. Edwards. Virginia Law Review, 1999, r. 85, č. 5, s. 805-851.

44 Viz POSNER, R. A. What Do Judges (and Justices) Maximize? (The Same Things Everyone Else Does). Supreme Court Economic Review, 1993, r. 3, s. 1-41.

45 Ostatně i v obecnějších debatách o významu deliberace v rozhodování mimo kontext studia soudů bývá zdůrazňován argument, že věnovat čas a úsilí deliberaci znamenat obětovat čas a úsilí, které bylo možno věnovat něčemu jinému, viz nap̌r. MCCUBBINS, M. D. a D. B. RODRIGUEZ. When Does Deliberating Improve Decisionmaking? Journal of Contemporary Legal Issues, 2006, r. 15, s. 9-50; nebo LUPIA, A. Deliberation Disconnected: What it Takes to Improve Civic Competence. Law and Contemporary Problems, 2002, r. 65, s. 133-150. 
Na stručně shrnutých teoretických základech lze identifikovat 4 základní ideální modely fungování soudního senátu. Je nutné poznamenat, že se jedná pouze o ideální teoretické modely, skutečné soudní senáty jim tedy nebudou bez dalšího dokonale odpovídat, mohou se jim však více či méně blížit. Jedná se o následující modely:

1. Konfliktni senát, $\mathrm{v}$ němž soudci v souladu s postojovým modelem hlasují o každém př́padu výhradně podle svého předem daného postoje nezávisle na senátních kolezích a v němž je hlasování často nejednotné. V tomto modelu senátní rozhodování plní zejména svou legitimizační funkci, s ohledem na malou šanci změny názoru jsou ostatní funkce omezeny;

2. Strategický senát, v němž soudci jednak již při tvorbě návrhu rozhodnutí anticipují př́stup svých kolegů a jednak vzájemně vyjednávají kompromisy. V důsledku toho se projevuje panelový efekt a výsledky senátního rozhodování jsou často jednomyslné, ale jsou ovlivněny postoji všech členů senátu. Senátní rozhodování v takovém senátu plní vedle funkce legitimizační i zbylé dvě funkce, byt' v limitované míre. V každém prrípadě v něm však soudci dosahují názorově kompromisních výsledků;

3. Kolegiálni senát, v němž soudci podrobně debatují všechny př́ipady a tím otupují hrany svých neshod - i v něm se silně projevuje panelový efekt. Senát plní ve vysoké míre všechny funkce senátního rozhodování, to však za cenu vysokých časových nákladů všech jeho členů;

4. Formální senát, v němž rozhodnutí fakticky závisí pouze na soudci, který připravil návrh rozhodnutí, ostatní soudci návrh zpravidla schvalují a rozhodování v senátu je tak prakticky jen formální. S ohledem na řídké diskuze plní senát jen slabě funkci směřující $\mathrm{k}$ dosažení promyšlenějšího řešení případu, ostatní dvě funkce však mohou zůstat zachovány, pokud je návrhu rozhodnutí věnována pozornost dostatečná alespoň pro eliminaci zjevných chyb.

\section{Senátní rozhodování a Ústavní soud ČR}

\subsection{Výzkumné otázky, hypotéza a metoda výzkumu}

Zbývající část tohoto textu se bude věnovat v úvodu vymezené hlavní otázce, nakolik má na rozhodování Ústavního soudu o ústavních stížnostech vliv osoba soudce zpravodaje a nakolik osoby dalších členů senátu. Vzhledem k tomu, že u Ústavního soudu ČR bývají v rozhodování o ústavních stížnostech pozorovány vysoké rozdíly v míre vstř́ícnosti př́stupu $\mathrm{k}$ jednotlivým stížnostem, bude výzkum zaměřen právě na tento ukazatel, a tedy na otázku, zda je míra vstřícnosti přístupu k ústavním stížnostem ovlivněna složením senátu Ústavního soudu.

Podle odpovědi na tuto otázku by mělo být možné přiblížit, který z výše identifikovaných modelů senátního rozhodování funguje na Ústavním soudu. Jak bylo naznačeno výše, v jeho prrípadě se lze domnívat, že senátní rozhodování může mít často blízko k modelu 
formálního senátu, $\mathrm{v}$ němž soudci zpravidla bez dalšího schválí řešení navržené zpravodajem. Naznačuje to velmi nízký počet odlišných stanovisek podávaných u Ústavního soudu v senátních věcech, ${ }^{46}$ jakož i výše zmiňované vyjádření Pavla Rychetského o průběhu projednávání ústavních stížností. Nahrává tomu navíc i procedura projednávání ústavních stížností, která soudcům v senátu snadno umožňuje spolehnout se na úsudek soudce zpravodaje, a zejména pak velmi vysoký nápad, který výrazně ztěžuje možnost všech členů senátu věnovat každému př́padu velkou pozornost: nápad se s každým rokem zvyšuje a např́klad v roce 2016 napadlo na Ústavní soud 4292 nových věcí. ${ }^{47}$ Jak spočítali Tereza Papoušková a Jan Papoušek, současní soudci (podle dat sesbíraných do poloviny roku 2016) mají většinou každý měsíc na starost v průměru mezi 20 a 30 věcmi jako zpravodajové, část věcí jsou přitom složitější věci plenární. ${ }^{48}$ Je zřejmé, že v takové situaci mohou soudci jen těžko věnovat srovnatelnou pozornost všem př́padům, které má na starost jiný zpravodaj a v nichž hlasují jako další členové senátu. Hlavní hypotézu výzkumu lze proto formulovat tak, že míra vstrǐcnosti senátu závisi prédevšim na osobě soudce zpravodaje a je jen minimálně ovlivnèna mírou vstrìcnosti ostatních členù senátu.

Vlastní výzkum byl proveden na vzorku obsahujícím všechna senátní rozhodnutí Ústavního soudu od 1. 2. 2007 do 31. 8. 2017, kterými bylo rozhodnuto o ústavní stížnosti tak, že jí bylo vyhověno, byla zamítnuta nebo odmítnuta pro zjevnou neopodstatněnost (Jedná se tedy o rozhodnutí, na nichž by se podle $\int 43$ zákona o Ústavním soudu měl podílet celý senát. U ostatních rozhodnutí odmítajících ústavní stížnosti z procesních důvodů může zpravodaj rozhodovat bez účasti zbylých členů senátu). Celkem se jedná o 28446 rozhodnutí. ${ }^{49}$ Časové ohraničení vzorku je dáno technickými možnostmi, nebot' u většiny starších rozhodnutí nebyla strojově evidována informace o složení senátu. Výzkum se zaměřuje na míru „vstřícnosti“ $\mathrm{k}$ jednotlivým stěžovatelům a sleduje jejî vývoj v závislosti na složení senátu a osobě soudce zpravodaje. S ohledem na vymezení datasetu je fakticky měřena míra vstřícnosti v prrípadech meritorního či kvazimeritorního projednávání ústavních stížností - tedy v př́padech, kdy byla stížnost podána včas, oprávněnou a řádně zastoupenou osobou a obsahuje všechny povinné náležitosti a soud rozhoduje pouze, zda je opodstatněná, neopodstatněná nebo zjevně neopodstatněná.

Je pochopitelně dobře představitelné, že způsob fungování senátů se může v praxi lišit při meritorním rozhodování o vyhovění stížnosti či jejím zamítnutí od rozhodování

46 To nevylučuje možnost, že soudci hlasovali nejednotně (s výjimkou usnesení o odmítnutí stížnosti pro zjevnou neopodstatněnost, která musí být jednomyslná). Údaje o hlasování senátư Ústavního soudu nejsou veřejné a nízký počet odlišných stanovisek je tak pouze nepřímým náznakem, nikoliv nezvratným důkazem, že v senátním rozhodování zřejmě nemusí docházet $\mathrm{k}$ neshodám príliš často.

47 Zdroj: Ročenka Ústavního soudu pro rok 2016. Dostupná z: https://www.usoud.cz/fileadmin/user_upload/ ustavni_soud_www/Aktualne_prilohy/Ustavni_soud_Rocenka_2016_nahled.pdf

48 PAPOUŠKOVÁ, PAPOUŠEK, op. cit., sub 3.

49 Rozhodnutí ve strojově zpracovatelné podobě spolu s údaji o složení senátu byla získána od Ústavního soudu pomocí žádosti o informace podle zákona č. 106/1999 Sb., o svobodném prúistupu k informacím. 
o odmítnutí pro zjevnou neopodstatněnost. ${ }^{50}$ Je možné, že nálezům ve věci samé členové senátu věnují ve skutečnosti větší pozornost, už proto, že jejich závaznosti je přikládán větší význam. ${ }^{51}$ Meritorní a „,kvazimeritorni““ rozhodnutí však přesto nebudou zkoumána separátně: zkoumání vzorku tak, jak byl zvolen, vypovídá obecně o tom, jak soudci přistupují těm rozhodnutím, která má ze zákona činit senát. Mezi nálezy navíc zcela jednoznačně k těm převažují vyhovující nad zamítavými (ve zkoumaném období z celkem 4136 nálezů obsahovalo 3668, tedy 88,7 \%, alespoň jeden vyhovující výrok) a zkoumat nálezy samostatně - odděleně od usnesení - by tedy při zvolené statistické metodě nebylo produktivní. Pokud by senátní rozhodování mělo v rámci plnění svých funkcí mimo jiné bránit př́liš přísným, nebo naopak př́liš vstř́icným rozhodnutím zpravodaje, musely by osoby dalších členů senátu mít vliv nejen na meritorní nálezy, ale i na usnesení o odmítnutí ústavní stížnosti pro zjevnou neopodstatněnost. Nutno dodat, že právě v jejich př́ipadě je možnost dalších členů senátu ovlivnit rozhodnutí posílena pravidlem, podle kterého lze ústavní stížnost odmítnout pro zjevnou neopodstatněnost pouze jednomyslně (ust. \ 19 odst. 2 zákona o Ústavním soudu).

Zkoumány budou postupně tři podotázky: 1) Existuje korelace mezi mírou vstř́cnosti, kterou soudci vykazují v pozici soudce zpravodaje, a mírou vstřícnosti, kterou vykazují v pozici dalšího člena senátu? 2) V jaké míře ovlivní soudce zpravodaje, pokud s ním v senátu rozhoduje soudce, který sám jako zpravodaj patří mezi nejvstřícnější nebo naopak nejméně vstřícné? 3) V jaké míre ovlivní soudce zpravodaje, pokud dva zbývající soudci jako zpravodajové oba patři mezi výrazně vstřícné nebo naopak výrazně nevstř́icné soudce?

\subsection{Soudce jako zpravodaj a jako další člen senátu}

Následující tabulka představuje přehled počtu rozhodnutí ve zkoumaném vzorku, $\mathrm{v}$ nichž jednotliví soudci rozhodovali v a) pozici soudce zpravodaje a b) člena senátu, a dále počtu a procenta rozhodnutí, $\mathrm{v}$ nichž $\mathrm{v}$ daných pozicích vyhověli ústavní stížnosti.

\begin{tabular}{|c|c|c|c|c|c|c|}
\hline & $\begin{array}{l}\text { Celkový } \\
\text { počet } \\
\text { rozhod- } \\
\text { nutí jako } \\
\text { zpravodaj }\end{array}$ & $\begin{array}{c}\text { Počet } \\
\text { vyhovění } \\
\text { jako zpra- } \\
\text { vodaj }\end{array}$ & $\begin{array}{l}\text { \% vyho- } \\
\text { vění jako } \\
\text { zpravodaj }\end{array}$ & $\begin{array}{c}\text { Počet } \\
\text { rozhodnutí } \\
\text { jako člen } \\
\text { senátu - } \\
\text { nezpravo- } \\
\text { daj }\end{array}$ & $\begin{array}{c}\text { Počet } \\
\text { vyhovění } \\
\text { jako člen } \\
\text { senátu - } \\
\text { nezpravo- } \\
\text { daj }\end{array}$ & $\begin{array}{c}\text { \% vy- } \\
\text { hovění } \\
\text { jako člen } \\
\text { senátu - } \\
\text { nezpravo- } \\
\text { daj }\end{array}$ \\
\hline Suchánek & 688 & 21 & $3,05 \%$ & 2131 & 154 & $7,23 \%$ \\
\hline Kůrka & 1719 & 58 & $3,37 \%$ & 3727 & 171 & $4,59 \%$ \\
\hline Musil & 2053 & 70 & $3,41 \%$ & 4774 & 227 & $4,75 \%$ \\
\hline Sládeček & 984 & 34 & $3,46 \%$ & 2140 & 114 & $5,33 \%$ \\
\hline
\end{tabular}

50 Za tuto poznámku děkuji jednomu z recenzentů Časopisu pro právní vědu a praxi.

51 Viz k tomu nález Ústavního soudu ze dne 13. 11. 2007 sp.zn. IV.ÚS 301/05. 


\begin{tabular}{|c|c|c|c|c|c|c|}
\hline & $\begin{array}{l}\text { Celkový } \\
\text { počet } \\
\text { rozhod- } \\
\text { nutí jako } \\
\text { zpravodaj }\end{array}$ & $\begin{array}{c}\text { Počet } \\
\text { vyhovění } \\
\text { jako zpra- } \\
\text { vodaj }\end{array}$ & $\begin{array}{l}\text { \% vyho- } \\
\text { vění jako } \\
\text { zpravodaj }\end{array}$ & $\begin{array}{l}\text { Počet } \\
\text { rozhodnutí } \\
\text { jako člen } \\
\text { senátu - } \\
\text { nezpravo- } \\
\text { daj }\end{array}$ & $\begin{array}{c}\text { Počet } \\
\text { vyhovění } \\
\text { jako člen } \\
\text { senátu - } \\
\text { nezpravo- } \\
\text { daj }\end{array}$ & $\begin{array}{c}\text { \% vy- } \\
\text { hovění } \\
\text { jako člen } \\
\text { senátu - } \\
\text { nezpravo- } \\
\text { daj }\end{array}$ \\
\hline Židlická & 1368 & 55 & $4,02 \%$ & 3326 & 185 & $5,56 \%$ \\
\hline Formánková & 1661 & 73 & $4,39 \%$ & 3820 & 205 & $5,37 \%$ \\
\hline Mucha & 1030 & 52 & $5,05 \%$ & 2173 & 90 & $4,14 \%$ \\
\hline Duchoň & 920 & 47 & $5,11 \%$ & 2192 & 261 & $11,91 \%$ \\
\hline Lichovník & 704 & 37 & $5,26 \%$ & 1700 & 113 & $6,65 \%$ \\
\hline Fiala & 436 & 23 & $5,28 \%$ & 777 & 44 & $5,66 \%$ \\
\hline Zemánek & 779 & 43 & $5,52 \%$ & 1973 & 145 & $7,35 \%$ \\
\hline Jirsa & 473 & 27 & $5,71 \%$ & 896 & 28 & $3,13 \%$ \\
\hline Holländer & 1020 & 59 & $5,78 \%$ & 343 & 17 & $4,96 \%$ \\
\hline Uhlír & 604 & 36 & $5,96 \%$ & 1421 & 113 & $7,95 \%$ \\
\hline Výborný & 1132 & 69 & $6,10 \%$ & 2706 & 107 & $3,95 \%$ \\
\hline Tomková & 547 & 34 & $6,22 \%$ & 0 & 0 & $\mathrm{x}$ \\
\hline David & 854 & 56 & $6,56 \%$ & 2008 & 153 & $7,62 \%$ \\
\hline Lastovecká & 1226 & 84 & $6,85 \%$ & 2801 & 207 & $7,39 \%$ \\
\hline Šimíček & 811 & 56 & $6,91 \%$ & 1402 & 79 & $5,63 \%$ \\
\hline Balík & 1387 & 96 & $6,92 \%$ & 3067 & 225 & $7,34 \%$ \\
\hline Nykodým & 1320 & 93 & $7,05 \%$ & 2783 & 195 & $7,01 \%$ \\
\hline Filip & 931 & 70 & $7,52 \%$ & 2234 & 92 & $4,12 \%$ \\
\hline Rychetský & 1043 & 86 & $8,25 \%$ & 242 & 6 & $2,48 \%$ \\
\hline Fenyk & 665 & 55 & $8,27 \%$ & 186 & 20 & $10,75 \%$ \\
\hline Janů & 1468 & 140 & $9,54 \%$ & 3126 & 277 & $8,86 \%$ \\
\hline Šimáčková & 1034 & 99 & $9,57 \%$ & 2291 & 161 & $7,03 \%$ \\
\hline Güttler & 1074 & 134 & $12,48 \%$ & 2644 & 211 & $7,98 \%$ \\
\hline Wagnerová & 515 & 93 & $18,06 \%$ & 2 & 0 & $0,00 \%$ \\
\hline CELKEM & 28446 & 1800 & $\begin{array}{c}\text { 6,33 \% } \\
\text { (průměr) }\end{array}$ & 56885 & 3600 & $\begin{array}{c}6,33 \% \\
\text { (průměr) }\end{array}$ \\
\hline
\end{tabular}

Tabulka ukazuje, že mezi mírou vstřícnosti, kterou soudci vykazují v pozici zpravodaje a v pozici dalšího člena senátu, existuje jen slabá korelace. Vyjádřeno číselně činí korelace pouze 0,27 (při vyloučení výsledku Elišky Wagnerové, která jako další člen senátu - nezpravodaj - rozhodovala pouze dvakrát a Milady Tomkové, která takto nerozhodovala nikdy). Ačkoliv by bylo možné očekávat, že soudci své „,nastaveni““ ohledně míry vstřícnosti k ústavním stížnostem vykazované v pozici zpravodaje přenášejí i do rozhodování v pozici dalšího člena senátu, uvedená slabá korelace tuto domněnku v žádném př́ípadě nepotvrzuje. 
Slabý vztah mezi vstřícností v pozici zpravodaje a v pozici dalšího člena senátu je viditelný i při pohledu na výsledky jednotlivých soudů: Vojen Güttler a Kateřina Šimáčková, kteří platí po Elišce Wagnerové za nejvstřícnější soudce zpravodaje, vyhovovali jako další členové senátu ústavním stížnostem jen v mírně nadprůměrném počtu prrípadů. To znamená, že pravděpodobně jen zřídka dokázali přesvědčit soudce zpravodaje o vstř́ícnějším přístupu (soudci zpravodaji $\mathrm{v}$ př́padech, kdy zasedala jako člen senátu Kateřina Šimáčková, byli v pořadí četnosti David Uhlíř - Ludvík David - Tomáš Lichovník - Ivana Janů - Jaroslav Fenyk; V př́padě Vojena Güttlera byli soudci zpravodaji Ivana Janů František Duchoň - Pavel Holländer - Eliška Wagnerová). Na druhé straně Radovan Suchánek platí za vůbec nejméně vstřícného soudce zpravodaje v historii Ústavního soudu, pokud je však pouze členem senátu, je procento vyhovění ústavním stížnostem dokonce nadprůměrné (v jeho př́padě byli soudci zpravodaji Josef Fiala - Jiří Zemánek - Vojtěch Šimíček - Jan Filip - Jaroslav Fenyk - Stanislav Balík). V jeho případě však připadá v úvahu i domněnka, že byl relativně často přehlasován senátními kolegy, o čemž může neprrímo svědčit poměrně velký počet jím podaných odlišných stanovisek v senátních věcech (celkem deset odlišných stanovisek v senátních věcech za dobu nástupu na Ústavní soud v roce 2013 do současnosti; je však pravdou, že pouze ve 4 případech šlo o disent k vyhovujícímu nálezu).

Vzhledem k tomu, že složení senátů na Ústavním soudu bylo v minulosti poměrně stabilní, jsou pochopitelně výsledky pro jednotlivé soudce ovlivněny tím, že soudci často tvořili senát s podobnými kolegy. Právě proto je třeba analýzu doplnit o zkoumání dalších výzkumných podotázek.

Za stručné povšimnutí stojí i skutečnost, že výsledky ve zkoumaném vzorku, v němž jsou pouze rozhodnutí o ústavních stížnostech, kde neexistovaly čistě procesní důvody pro odmítnutí, ukazují ještě o něco dramatičtější rozdíl mezi nejvstřícnějším soudcem zpravodajem a zpravodajem nejméně vstřícným, než v úvodu článku citované výzkumy, které se zaměřovaly poměr vyhovění ze všech podaných ústavních stížností. Nutno dodat, že v pozici dalších členů senátu soudci vykazují výrazně menší rozdíly.

\subsection{Vstřícný nebo naopak nevstř́ícný člen senátu}

Dále se zaměřme na otázku, zda soudce zpravodaje nějak ovlivňuje, pokud s ním v senátu rozhoduje soudce, který sám platí za výrazně vstřícného nebo naopak nevstřícného soudce zpravodaje. Pokud by se v senátním rozhodování Ústavního soudu projevoval panelový efekt, měl by zpravodaj při účasti vstřícného soudce v senátu sám projevovat vyšší vstřícnost oproti svému průměru: bud' s ohledem na strategickou úvahu, nebo pod vlivem argumentů, které vstřícný soudce vznese pro vyhovění ústavní stížnosti v průběhu senátních diskuzí (pokud nějaká diskuze proběhne). Obdobně by se v př́padě účasti nevstrícného soudce měl projevovat právě opačný efekt. 
Následující tabulky pro tři nejvstřícnější a tři nejméně vstřícné soudce zpravodaje (s výjimkou Elišky Wagnerové, která prakticky nezasedala jako další člen senátu) ukazují, zda a nakolik se při jejich př́tomnosti v senátu jednotliví soudci zpravodajové odchýlili od svého průměru v míre vstřícnosti. $\mathrm{V}$ záhlaví tabulky je uveden zkoumaný soudce a procento vyhovění, které sám vykazuje v pozici zpravodaje. $\mathrm{V}$ tabulce jsou následně uvedeni soudci zpravodajové, kteří se zkoumaným soudcem ve více než sto prrípadech rozhodovali jako s dalším členem senátu a srovnání jejich celkové míry vstřícnosti s mírou vstř́ícnosti vykazovanou prri rozhodování se zkoumaným soudcem.

\begin{tabular}{|c|c|c|c|c|c|c|c|c|}
\hline \multicolumn{9}{|c|}{ Nejvstřícnější soudci } \\
\hline \multicolumn{3}{|c|}{$\begin{array}{c}\text { Vojen Güttler } \\
(12,48 \%)\end{array}$} & \multicolumn{3}{|c|}{$\begin{array}{c}\text { Kateřina Šimáčková } \\
(9,57 \%)\end{array}$} & \multicolumn{3}{|c|}{$\begin{array}{l}\text { Ivana Janů } \\
(9,54 \%)\end{array}$} \\
\hline $\begin{array}{c}\text { soudce } \\
\text { zpravodaj }\end{array}$ & $\begin{array}{c}\text { \% vy- } \\
\text { hovění } \\
\text { zpra- } \\
\text { vodaje } \\
\text { celkem }\end{array}$ & $\begin{array}{l}\text { \% vy- } \\
\text { hovění } \\
\text { s členem } \\
\text { senátu }\end{array}$ & $\begin{array}{l}\text { soudce } \\
\text { zpravodaj }\end{array}$ & $\begin{array}{l}\text { \% vy- } \\
\text { hovění } \\
\text { zpra- } \\
\text { vodaje } \\
\text { celkem }\end{array}$ & $\begin{array}{l}\text { \% vy- } \\
\text { hovění } \\
\text { s členem } \\
\text { senátu }\end{array}$ & $\begin{array}{l}\text { soudce } \\
\text { zpravodaj }\end{array}$ & $\begin{array}{l}\text { \% vy- } \\
\text { hovění } \\
\text { zpra- } \\
\text { vodaje } \\
\text { celkem }\end{array}$ & $\begin{array}{c}\% \text { vy- } \\
\text { hovění } \\
\text { s členem } \\
\text { senátu }\end{array}$ \\
\hline Duchoň & $5,11 \%$ & $5,11 \%$ & David & $6,56 \%$ & $6,64 \%$ & David & $6,56 \%$ & $5,38 \%$ \\
\hline Holländer & $5,78 \%$ & $3,79 \%$ & Fenyk & $8,27 \%$ & $8,77 \%$ & Duchoň & $5,11 \%$ & $5,11 \%$ \\
\hline Janů & $9,54 \%$ & $9,63 \%$ & Janů & $9,54 \%$ & $9,34 \%$ & Güttler & $12,48 \%$ & $12,32 \%$ \\
\hline \multirow[t]{4}{*}{ Wagnerová } & $18,06 \%$ & $19,14 \%$ & Lichovník & $5,26 \%$ & $4,97 \%$ & Holländer & $5,78 \%$ & $3,40 \%$ \\
\hline & & & Uhlír & $5,96 \%$ & $5,96 \%$ & Rychetský & $8,25 \%$ & $9,48 \%$ \\
\hline & & & & & & Šimáčková & $9,57 \%$ & $8,39 \%$ \\
\hline & & & & & & Wagnerová & $18,06 \%$ & $22,09 \%$ \\
\hline \multicolumn{9}{|c|}{ Nejméně vstřícní soudci } \\
\hline \multicolumn{3}{|c|}{ Radovan Suchánek $(3,05 \%)$} & \multicolumn{3}{|c|}{ Vladimír Kůrka (3,37 \%) } & \multicolumn{3}{|c|}{ Jan Musil (3,41 \%) } \\
\hline $\begin{array}{c}\text { soudce } \\
\text { zpravodaj }\end{array}$ & $\begin{array}{c}\text { \% vy- } \\
\text { hovění } \\
\text { zpra- } \\
\text { vodaje } \\
\text { celkem }\end{array}$ & $\begin{array}{l}\text { \% vy- } \\
\text { hovění } \\
\text { s členem } \\
\text { senátu }\end{array}$ & $\begin{array}{l}\text { soudce } \\
\text { zpravodaj }\end{array}$ & $\begin{array}{l}\text { \% vy- } \\
\text { hovění } \\
\text { zpra- } \\
\text { vodaje } \\
\text { celkem }\end{array}$ & $\begin{array}{c}\text { \% vy- } \\
\text { hovění } \\
\text { s členem } \\
\text { senátu }\end{array}$ & $\begin{array}{l}\text { soudce } \\
\text { zpravodaj }\end{array}$ & $\begin{array}{l}\text { \% vy- } \\
\text { hovění } \\
\text { zpra- } \\
\text { vodaje } \\
\text { celkem }\end{array}$ & $\begin{array}{c}\text { \% vy- } \\
\text { hovění } \\
\text { s členem } \\
\text { senátu }\end{array}$ \\
\hline Balík & $6,92 \%$ & $9,92 \%$ & Filip & $7,52 \%$ & $6,37 \%$ & Fenyk & $8,27 \%$ & $8,91 \%$ \\
\hline Fenyk & $8,27 \%$ & $11,27 \%$ & Holländer & $5,78 \%$ & $5,83 \%$ & Filip & $7,52 \%$ & $6,11 \%$ \\
\hline Fiala & $5,28 \%$ & $5,28 \%$ & Mucha & $5,05 \%$ & $4,74 \%$ & Holländer & $5,78 \%$ & $5,51 \%$ \\
\hline Filip & $7,52 \%$ & $9,32 \%$ & Musil & $3,41 \%$ & $3,34 \%$ & Jirsa & $5,71 \%$ & $6,32 \%$ \\
\hline Šimíček & $6,91 \%$ & $7,24 \%$ & Rychetský & $8,25 \%$ & $7,50 \%$ & Kůrka & $3,37 \%$ & $3,42 \%$ \\
\hline \multirow[t]{4}{*}{ Zemánek } & $5,52 \%$ & $5,45 \%$ & & & & Mucha & $5,05 \%$ & $5,03 \%$ \\
\hline & & & & & & Rychetský & $8,25 \%$ & $7,72 \%$ \\
\hline & & & & & & Sládeček & $3,46 \%$ & $2,76 \%$ \\
\hline & & & & & & Tomková & $6,22 \%$ & $4,10 \%$ \\
\hline
\end{tabular}


Výsledky ukazují jen malý a v některých př́padech nulový vliv vstřícného nebo naopak nevstřícného člena senátu na soudce zpravodaje. V senátním rozhodování Ústavního soudu se tedy - pokud jde o míru vstřícnosti - panelový efekt projevuje pouze minimálně. Byl-li členem senátu Vojen Güttler, vyhovovali soudci zpravodajové ústavním stížnostem podobně často, jako pokud členem senátu nebyl: Eliška Wagnerová nepatrně častěji, Pavel Holländer naopak o něco méně často. Žádný pozitivní vliv na míru vstř́ícnosti soudců zpravodajů nelze vysledovat ani u Kateřiny Šimáčkové a Ivany Janů. Výjimkou je snad jen nezvykle vysoká šance stěžovatelů na úspěch v př́padech, kdy byla soudkyní zpravodajkou Eliška Wagnerová a členkou senátu Ivana Janů (22,09 \%, tedy ještě o 4 \% vyšší šance, než činí průměr Elišky Wagnerové. V této konstelaci soudkyně rozhodovaly 163 x a vyhověly 36 ústavním stížnostem, což je však ze statistického hlediska poměrně malý vzorek).

V př́padě nejméně vstřícných soudců se zdá, že určitý mírný vliv na soudce zpravodaje mohli mít Vladimír Kůrka a Jan Musil, při jejichž prrítomnosti v senátu rozhodovalo hned několik soudců zpravodajů mírně „přísněji“ oproti svému průměru. $\mathrm{Na}$ druhou stranu, výsledek Radovana Suchánka překvapivě ukazuje právě opačný obrázek: ačkoliv sám jako soudce zpravodaj vyhovuje ústavním stížnostem jen zcela výjimečně, pokud je členem senátu, mívají stěžovatelé u jednotlivých soudců zpravodajů dokonce větší úspěch, než je pro dané zpravodaje obvyklé.

V některých př́padech je i zde výsledek určen tím, že určitý soudce zpravodaj měl zkoumaného soudce vždy nebo velmi často za dalšího člena senátu. To platí pro Františka Duchoně jako soudce zpravodaje a Vojena Güttlera a Ivanu Janů jako jeho členy senátu (František Duchoň bez nich jako soudce zpravodaj nerozhodoval ani jednou). Stejně tak Josef Fiala nikdy nerozhodoval jako soudce zpravodaj, aniž by členem senátu byl Radovan Suchánek. Z celkem 1030 prrípadů, kdy byl soudcem zpravodajem Jiř́i Mucha, nebyl jen 38 x členem senátu Vladimír Kưrka a 36 x Jan Musil. K tomu je třeba při hodnocení dat prihlédnout.

\subsection{Dva vstrúícní nebo naopak nevstřícní členové senátu}

Závěry o slabé korelaci mezi vstř́ícností vykazovanou v pozici zpravodaje a v pozici člena senátu a o slabém panelovém efektu v senátním rozhodování implikují domněnku, že v rozhodování Ústavního soudu má výrazně dominantní roli soudce zpravodaj. Tuto domněnku ověřuje poslední z tabulek vztahující se k poslední zkoumané podotázce: jaký vliv na soudce zpravodaje má, pokud zbytek senátu tvoří soudci, kteří oba patří mezi nejvíce nebo naopak nejméně vstř́ícné. Následující tabulka ukazuje, nakolik byla ovlivněna míra vstřícnosti jednotlivých soudců zpravodajů v prrípadech, kdy rozhodovali se dvěma členy senátu, kteří sami jako zpravodajové patří mezi sedm nejméně, nebo naopak nejvíce vstřícné soudce zpravodaje (zahrnuty jsou znovu pouze výsledky, kdy existovalo alespoň sto takových rozhodnutî). 


\begin{tabular}{|c|c|c|c|c|c|c|}
\hline \multicolumn{7}{|c|}{ Nejméně vstřícní soudci jako dva členové senátu } \\
\hline $\begin{array}{l}\text { členové } \\
\text { senátu }\end{array}$ & $\begin{array}{l}\text { celkový počet } \\
\text { společných } \\
\text { rozhodnutí } \\
\text { dvou členů } \\
\text { senátu }\end{array}$ & zpravodaj & $\begin{array}{c}\text { celkový } \\
\text { počet roz- } \\
\text { hodnutí } \\
\text { zpravodaje }\end{array}$ & $\begin{array}{c}\text { počet } \\
\text { společných } \\
\text { rozhodnutí } \\
\text { členů senátu } \\
\text { se zpravoda- } \\
\text { jem }\end{array}$ & $\begin{array}{l}\text { procento } \\
\text { vyhovění } \\
\text { v daném } \\
\text { složení }\end{array}$ & $\begin{array}{l}\text { procento } \\
\text { vyhovění } \\
\text { zpravodaje } \\
\text { celkem }\end{array}$ \\
\hline \multirow[t]{3}{*}{ Kůrka, Musil } & 1834 & Filip & 931 & 538 & $6,13 \%$ & $7,52 \%$ \\
\hline & & Holländer & 1020 & 127 & $4,72 \%$ & $5,78 \%$ \\
\hline & & Rychetský & 1043 & 140 & $7,14 \%$ & $8,25 \%$ \\
\hline \multirow[t]{2}{*}{ Mucha, Musil } & 1088 & Holländer & 1020 & 127 & $6,30 \%$ & $5,78 \%$ \\
\hline & & Kůrka & 1719 & 918 & $3,59 \%$ & $3,37 \%$ \\
\hline $\begin{array}{l}\text { Mucha, } \\
\text { Kůrka }\end{array}$ & 1008 & Musil & 2053 & 864 & $3,59 \%$ & $3,41 \%$ \\
\hline \multirow{2}{*}{$\begin{array}{l}\text { Formánková, } \\
\text { Sládeček }\end{array}$} & 580 & Lichovník & 704 & 234 & $4,70 \%$ & $5,26 \%$ \\
\hline & & Židlická & 1368 & 269 & $5,58 \%$ & $4,02 \%$ \\
\hline $\begin{array}{l}\text { Sládeček, } \\
\text { Židlická }\end{array}$ & 204 & Formánková & 1661 & 201 & $7,96 \%$ & $4,39 \%$ \\
\hline \multirow{2}{*}{$\begin{array}{l}\text { Formánková, } \\
\text { Židlická }\end{array}$} & 1575 & Holländer & 1020 & 132 & $10,61 \%$ & $5,78 \%$ \\
\hline & & Sládeček & 984 & 250 & $4,00 \%$ & $3,46 \%$ \\
\hline \multicolumn{7}{|c|}{ Nejvstřícnější soudci jako dva členové senátu } \\
\hline $\begin{array}{l}\text { členové } \\
\text { senátu }\end{array}$ & $\begin{array}{l}\text { celkový počet } \\
\text { společných } \\
\text { rozhodnutí } \\
\text { dvou členù } \\
\text { senátu }\end{array}$ & zpravodaj & $\begin{array}{c}\text { celkový } \\
\text { počet roz- } \\
\text { hodnutí } \\
\text { zpravodaje }\end{array}$ & \begin{tabular}{|} 
počet \\
společných \\
rozhodnu- \\
tí celého \\
senátu
\end{tabular} & $\begin{array}{c}\text { procento } \\
\text { vyhovění } \\
\text { senátu }\end{array}$ & $\begin{array}{l}\text { procento } \\
\text { vyhovění } \\
\text { soudce } \\
\text { zpravodaje }\end{array}$ \\
\hline Guttler, Janů & 1305 & Holländer & 1020 & 264 & $3,79 \%$ & $5,78 \%$ \\
\hline $\begin{array}{l}\text { Janů, } \\
\text { Šimáčková }\end{array}$ & 230 & David & 854 & 221 & $5,43 \%$ & $6,56 \%$ \\
\hline
\end{tabular}

Ani v tomto případě nelze pozorovat výrazný vliv dalších členů senátu na soudce zpravodaje. S výjimkou dvojice Kůrka - Musil v pozici dalších členů senátu se zdá, že žádná z dvojic vstřícných nebo naopak nevstřícných členů senátu výrazně nevychýlila soudce zpravodaje od jeho průměru, co se týče míry vstřícnosti. V případě málo vstřícných soudců se ovšem znovu může projevovat skutečnost, že senáty na Ústavním soudě tradičně rozhodovaly ve stabilním složení. Zejména trojice Kůrka - Musil - Mucha (III. senát „druhého“ Ústavního soudu) spolu rozhodovala dlouhodobě a zároveň každý jejî člen dlouhodobě patřil mezi nejméně vstřícné soudce zpravodaje. Výsledky ovšem současně ukazují, že soudci Musil a Kůrka od „přísného“ přístupu k ústavním stížnostem 
neustoupili, ani pokud rozhodovali se senátem $\mathrm{v}$ jiném složení (v několika stovkách př́padů, kdy jako soudce zpravodaj rozhodovali Vladimír Kůrka nebo Jan Musil, byl členem senátu Jan Filip; Jan Musil jako soudce zpravodaj rozhodoval také s Michaelou Židlickou, Jaromírem Jirsou a Vladimírem Sládečkem).

\section{Závěr}

Z výsledků výzkumu plyne, že obecnou míru vstřícnosti ve vztahu k ústavním stížnostem určuje především přístup soudce zpravodaje. Role dalších členů senátu je omezená v tom smyslu, že jejich vlastní vstřícný nebo nevstř́ícný přístup ke stížnostem jen málo ovlivňuje výsledek ř́zení.

Výzkum má s ohledem na zvolenou výzkumnou otázku i metodu určité limity a nemá $\mathrm{v}$ žádném př́padě ambici komplexně popsat podobu senátního rozhodování Ústavního soudu. Statistická metoda pochopitelně nepostihuje konkrétní okolnosti jednotlivých případů a $z$ naznačeného pozorování proto nepochybně existuje dlouhá řada výjimek, $\mathrm{v}$ nichž byl soudce zpravodaj přesvědčen argumenty členů senátu. Výzkum navíc kvůli nedostupnosti potřebných dat nezohledňuje př́pady, $\mathrm{v}$ nichž $\mathrm{v}$ průběhu řízení došlo $\mathrm{k}$ výměně soudce zpravodaje. Výsledky dále nevypovídají o vlivu členů senátu na text odůvodnění jednotlivých rozhodnutí a stranou pozornosti byla ponechána také otázka odlišných stanovisek v senátním rozhodování. Přesto mám za to, že výzkum má - s uvedenými výhradami - vypovídací hodnotu, nebot' naznačuje základní obecný trend, pokud jde o otázku, nakolik ovlivňuje vyhovění či nevyhovění ústavním stížnostem soudce zpravodaj a nakolik další členové senátu.

Výsledky ohledně všech tří zkoumaných podotázek tedy naznačují, že v senátním rozhodování Ústavního soudu o ústavních stížnostech se projevuje výrazně dominantní role soudce zpravodaje. Zdá se, že mezi jednotlivými modely soudních senátů má senátní rozhodování Ústavního soudu nejblíže k formálnímu modelu, v němž je zvykem obvykle bez dalšího prijíimat zpravodajský návrh, spíše než hlasovat po svém nebo rozsáhle o jednotlivých př́padech diskutovat, a $\mathrm{v}$ němž ani zpravodaj předem nepřizpůsobuje svůj návrh tomu, s kým o dané věci rozhoduje. Tento model fungování senátů je problematický v tom ohledu, že senátní rozhodování ztrácí funkci, v jejímž rámci by senátní diskuze měly vést $\mathrm{k}$ promyšlenějšímu řešení př́padů. $\mathrm{Na}$ druhou stranu je pravděpodobné, že na Ústavním soudě plní senátní rozhodování jednak tu funkci, že umožňuje odstranění zjevných chyb, kterých se př́padně dopustí soudce zpravodaj, a jednak zvyšuje legitimitu rozhodnutí v tom smyslu, že jej odsouhlasili tři soudci, a nikoliv pouze jediný. Lze ovšem prripomenout, že zákon o Ústavním soudu předpokládá, že o ústavních stížnostech bude rozhodovat senát, a nikoliv jen soudce zpravodaj. Je pochopitelně otevřenou otázkou, zda je tento zákonný požadavek, který je, jak se zdá, často naplňován pouze formálně, zcela adekvátní. 
Jak již ovšem bylo uvedeno, z výsledků nelze naznačený způsob fungování dovodit s absolutní jistotou - pro takové závěry by bylo nutné výzkum výrazně rozšíriti a doplnit o další - kvalitativní - metody. Vedle toho by bylo na místě zaměřit se i na jiné ukazatele, než je obecná míra vstríícnosti zpravodajů a členů senátu, např́ílad nakolik senátní rozhodování ovlivňuje specifická míra vstrúícnosti soudců ve vztahu k jednotlivým právním oblastem, profesní složení soudců, jejich ideologické přesvědčení atd. Výsledky navíc vypovídají (a z podstaty statistického výzkumu tomu nemůže být jinak) pouze o tom, jak pravděpodobně vètšinou funguje senátní rozhodování $\mathrm{v}$ př́padech, $\mathrm{v}$ nichž má podle zákona rozhodovat senát. Není však vyloučeno, že v řadě konkrétních případů má senátní rozhodování odlišnou podobu - zejména si něco takového lze představit u meritorních nálezů, u nichž může být pozice zpravodaje slabší - vzhledem $\mathrm{k}$ tomu, že mezi těmito nálezy je jen minimum zamítavých, nelze tuto hypotézu pomocí statistiky dost dobře ověrit.

To však nic nemění na závěru, že problematické rozdíly ve vstř́ícnosti jednotlivých soudců zpravodajů Ústavního soudu, které pozorovala právní věda již v minulosti, nejsou výrazně zmírňovány působením dalších členů senátu. Výsledky výzkumu jsou v tomto směru ovlivněny skutečností, že na „druhém“ Ústavním soudě dlouhodobě fungovaly senáty v poměrně stabilním složení, v nichž bylo možné očekávat vyšší vzájemnou důvěru soudců. Pokud jde o řešení problému značných rozdílů $v$ míre vstřícnosti jednotlivých zpravodajů, může být krokem správným směrem nedávno zavedené pravidelné obměňování složení senátů - byt' dvouletá frekvence obměňování se do budoucna může ukázat jako př́liš nízká. 